\title{
Process-based approach to organizing the accounting of labor costs and motivation in the digital economy
}

\author{
Roman Blizkyi ${ }^{1, *}$, Olga Timokhina ${ }^{2}$, Tatyana Vlasova $^{2}$, and Yekaterina Gavrish ${ }^{3}$ \\ ${ }^{1}$ State University of Management, Moscow, Russia \\ ${ }^{2}$ Belgorod State National Research University, Belgorod, Russia \\ ${ }^{3}$ Kuban State Technological University, Krasnodar, Russia
}

\begin{abstract}
The article discusses the main risks of accounting for settlements with personnel in modern conditions, including those caused by significant changes in legislation, in terms of regulating the procedure for implementing expenses for labor remuneration. The authors systematized the main risks pursuant to a number of basic accounting criteria: purpose, order, content. The proposed approach, in contrast to the existing approaches, allows to quickly segment problematic risk areas of work in accounting. The article presents the characteristics of accounting procedures in the course of reflecting operations related to the accrual, retention and payment of wages, considering the conditions of digital transformation, where, in contrast to the existing approaches, the aspects of the influence of endo- and exogenous factors in the dynamics of the development of digital transformations are systematized. The content of IAS 19 Employee Benefits has been structured by different types of benefits. The criteria for recognizing the fact of remuneration are considered, a critical assessment of the classification and approaches to different types of remuneration in the context of noonomics is given.
\end{abstract}

\section{Introduction}

The modern model of business development is inherently associated with the efficient use of various resources, expanded opportunities for the use of innovative capital, investments and other advantages of models for organizing business processes in the context of a variety of exogenous and endogenous factors of company development. Herewith, one of the most important types of capital is human capital, which is identified with the extreme point of the maximum effects of systems that have the properties of dynamism, innovation and creativity. Human capital management (hereinafter - HCM) is one of the complex management processes, where, within the framework of accounting rules, procedures and forms of interaction, socio-economic interests are affected, often opposite to the interests of various participants in business processes - stakeholders. Thus, the awareness of the essence and fundamentality of building systems of labor relations, the order of interactions of interests

\footnotetext{
* Corresponding author: blizkeyRS@ gmail.com
} 
(motivations) arising in the process of economic life of economic entities and, above all, in the accounting and analytical and accounting and control environment (operations of accrual, payment, payroll) formed a scientific interest in the development of conceptual approaches of the chosen direction of research and its relevance.

\section{Material and methods}

The methodological and theoretical basis of the study was formed by a balance of research results in the field of constructing optimal motivational decisions and organizing accounting operations to reflect wages (remuneration) by such foreign authors as Amir. E. (1996), Britchenko, I. (2018), Romich, J. (2006), Miele, D. \& Scholer, A. (2018), Mendoza, E. \& Quadrini, V (2009), Naughton, J. (2019), Smith, J. \& Rezaee, Z. (1995), Zafar, T. (2021).

The work used the results of fundamental research in the field of assessing the accounting and analytical space and the effects that arise in different business models, business processes of using human capital, motivation, ways of reflecting wages (remuneration) in companies and the corresponding assessment of digital transformations in the economy, prevailing in Russian practice, by such scientists as: (2019).

The study was disclosed using the following methodological tools:

- general scientific and special methods, which made it possible to determine the main risks in the organization of accounting for settlements with personnel in modern conditions. So during the Covid-19 period, the governments of many countries make decisions on stabilization in three key areas: providing mechanisms to counter the negative impact of the Covid-19 virus, restarting economies in uncertain conditions, and providing conditions that enhance the survival of the population. Against this background, new regulations are being adopted, including those regulating labor costs. The authors systematized the main risks pursuant to a number of basic accounting criteria: purpose, procedure, reporting forms. The proposed approach, in contrast to the existing approaches, allows to quickly segment problematic risk areas of work in accounting;

- the accounting method and its elements, the grouping method, which made it possible to highlight the features of the process approach for assessing the characteristics of accounting procedures considering the conditions of digital transformations when reflecting the events and facts of the activities of organizations related to the operations of accrual, withholding and payment of wages, where, in contrast to the existing approaches, the aspects of the influence of endo- and exogenous factors in the dynamics of the development of digital transformations are systematized;

- structural analysis, which made it possible to structure the procedure for reflecting information in financial statements, pursuant to the requirements of IAS, focuses on improving the criteria for recognizing the fact of remuneration, through liability and expenses, in our opinion, they can be supplemented based on the practice of applying accounting elements.

\section{Results of the study}

The activities of each organization, various operations with personnel arise in relation to the accrual and payment of wages, settlements on accountable amounts and other transactions.

The accounting process, covering the recording of labor costs, has always been one of the most important parts of the accounting department of any company. The level of exactingness and responsibility for the work of an accountant in this area of operations is emphasized by the intensity of changes in regulatory legal acts, resolutions, and pursuant to 
Anikin, V. (2018), even on the adopted court decisions regulating the relevant area of the right to apply labor relations. We will draw up a diagram of the set of accounting rules covering the accounting of personnel remuneration (Figure 1).

\section{REQUIREMENTS FOR MAINTENANCE OF ACCOUNTING RECORDS}

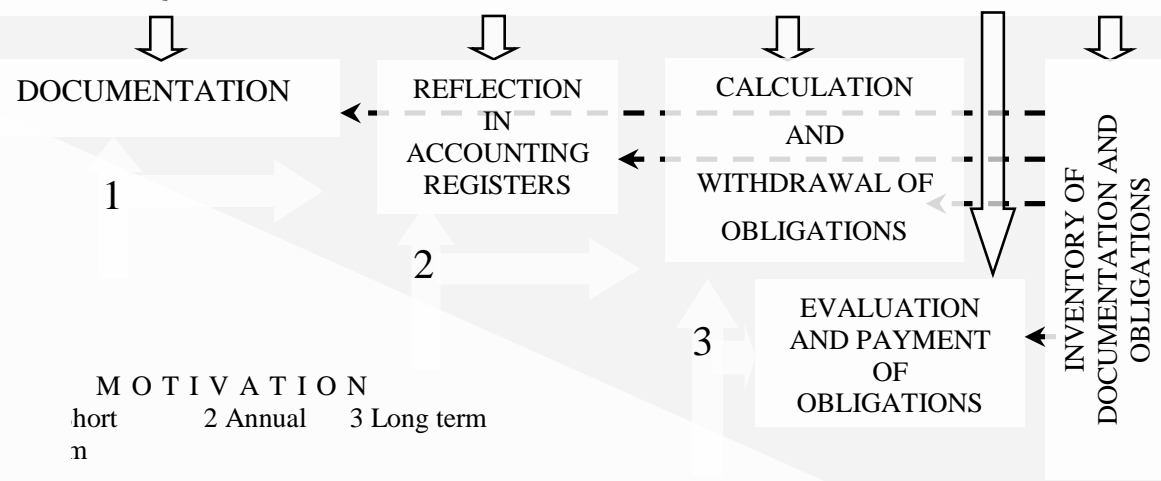

Fig. 1. A set of rules for accounting for wages as a method of staff motivation.

Figure 1 shows the relationship between compliance with payroll accounting requirements, its sequential processes and staff motivation. Carrying out control procedures aimed at optimizing the ratio between the dynamics of labor productivity growth and the corresponding wages of employees and their level of costs, the employer forms, at least, an estimated position in terms of the efficiency of management decisions. The content of the costs of paying employees of the organization, considering the compulsory insurance contributions for social insurance, is one of the items of production costs that form the cost of production, and, accordingly, affects the financial result of the enterprise. The works of the Indonesian scientist Zafar, T. (2021) additionally emphasize the role, significance and the effects that form compensation payments in the context of Covid-19 as a tool to motivate employees to work.

The views of different scientists emphasize the importance of considering process approaches when transforming the environment of companies' activities. Thus, Amir, E. (1996) identifies a process approach to the procedure for choosing a number of parameters for evaluating the empirical data of companies in the formation of financial statements; Britchenko, I. (2018) highlights the processes of harmonization of elements of the accounting environment in public sector structures; of practical interest are the results of Miele, D. \& Scholer, A. (2018), which provide an approximation of the qualitative properties of the process of monitoring the construction of an efficient motivation system and its impact on management; Let us highlight the position of Mendoza, E. \& Quadrini, V (2009), who use the processor approach in interpreting the iterative time proportions of financial integration and financial development of capital in the context of globalization. Thus, implementing the above experience of applying the process approach, one should consider the specifics, iterations and interpretation of situations that arise in the accounting and financial environment of companies. In the accounting policy of the company, it is necessary to include up-to-date schemes of postings and workflow for accounting procedures, including those related to the accrual, withholding and payment of wages. Figure 2 shows the features of evaluating the process approach of accounting procedures for accrual, deduction and payment of wages. 


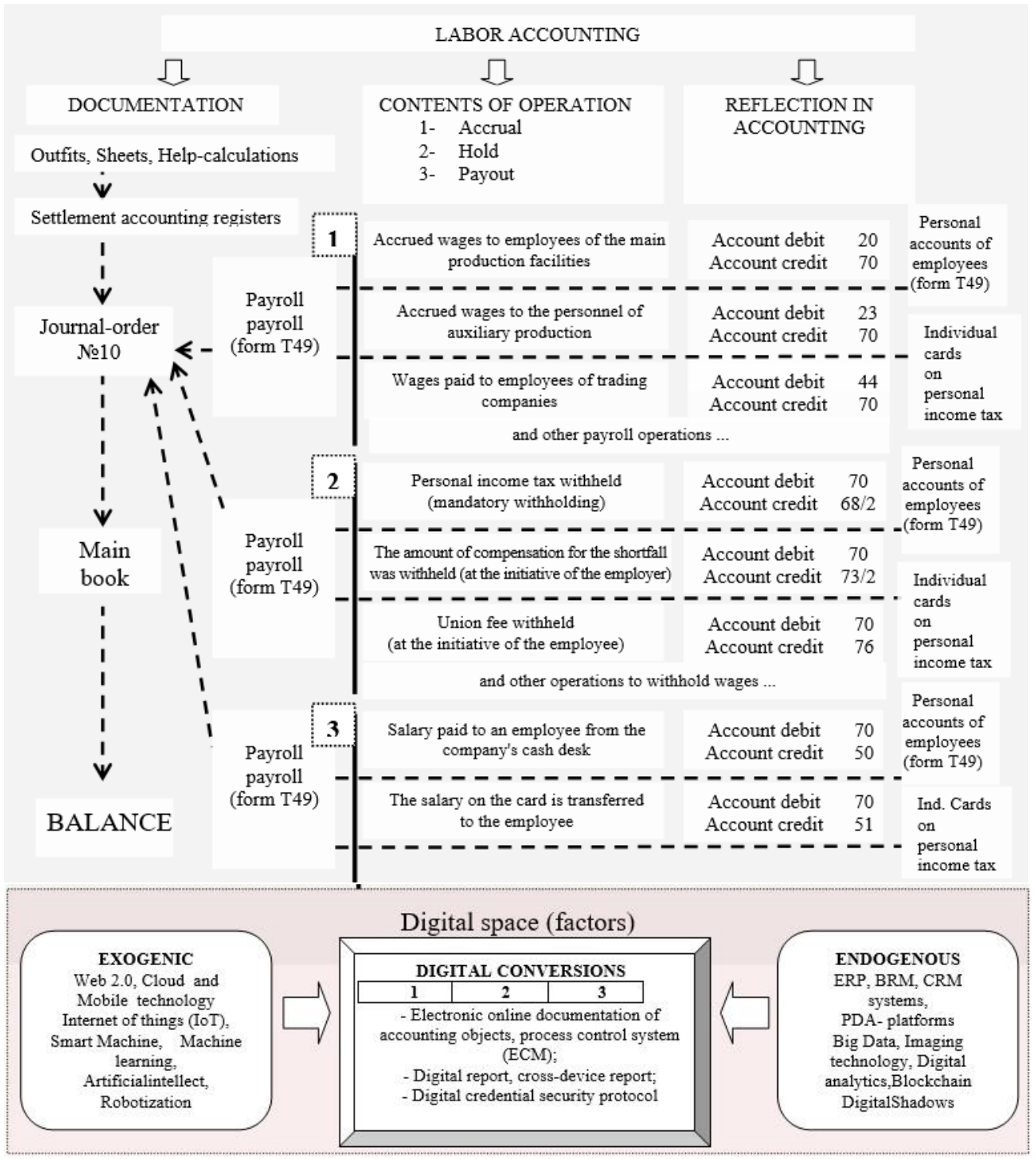

Fig. 2. Features of evaluating the process approach of accounting procedures for the accrual, deduction and payment of wages, considering the conditions of digital transformations.

As can be seen in Figure 2, accounting procedures are quite specific in their approaches and features in terms of reflecting, accruing, withholding and paying wages. Schemes of accounting procedures should be developed for all types of deductions with an indication of the primary documents in order to make the necessary changes in a timely manner. The presence of such documents will ensure that payments and deductions are carried out pursuant to the requirements of the law. In order to eliminate counting errors, it is necessary to establish by order a monthly reconciliation of primary documents on payroll with the results reflected in the General Ledger. In the works of the authors Blizkyi, R., Malinenko, V. and Lebedinskaya, Y. (2021b), transformations in the conditions of digital transformations are considered, the presented author's hypotheses form different views on changes in the future, but in general the authors agree on the position of the inevitability of changes in the practice of application elements of the accounting method. Thus, the factors of digital 
transformations highlighted by the authors in the modern conditions of the formation of the sixth technological order indicate changes in all sectors of the economy and imminent changes in accounting in terms of documentation, reporting and construction of new protocols for the security of credentials.

The prepared annual collection of the auditing company PwC Academy: ACCA training DipIFR (2020) forms an integrated approach to filling financial statements pursuant to international financial reporting standards (hereinafter referred to as IFRS). Since 2012, The Russian Federation (hereinafter - RF) is a member of the World Trade Organization and from that time, having received both certain preferences in partnerships in world trade and assuming certain obligations, the RF gradually began to introduce the use of IFRS into accounting procedures in companies forming a consolidated financial reporting. The transformations were aimed at the accessibility, comprehensibility, transparency and reliability of the reflection of information in the reporting of organizations. The global economic trends in technology cooperation and the globalization of business processes have actively influenced the development of the use of common and uniform standards for reflecting indicators in financial statements.

The relevant part of the study is the structuring and consideration of the application of IAS 19. From 01/01/2021, the international standard began to be applied and began to have legal force in the territory of the Russian Federation for those companies that prepare financial consolidated statements. The main purpose of IAS 19 is to provide guidance on the disclosure of information on employee benefits, as well as on accounting for pension plans. Thus, the company should clearly consider the signs of employee participation pursuant to two simultaneous criteria: responsibility (at the time the employee provides services in exchange for remuneration paid in the future) and costs (at the time the employer receives economic benefits arising from the use of services). If this simple algorithm is violated, then it is not recommended to recognize any rewards in the accounting.

It is not recommended to apply IAS 19 stand-alone from other IFRSs in accounting practice when preparing financial statements, therefore it closely correlates with IAS 1 "Presentation of financial statements", IFRS 2 "Share-based payment", IAS26 "Accounting and reporting by retirement benefit plans".

IAS 19 makes the following assumptions related to the recognition of benefits arising in the process:

- formation of formal agreements between an employee (groups of employees) and their representatives;

- informal practices that generate constructive engagement;

- legal requirements (determined by law).

There are four main types of rewards:

- current / short-term remuneration;

- various types of benefits;

- other long-term rewards;

- severance pay.

In Figure 3, we structure the procedure for reflecting information in financial statements, pursuant to the requirements of IAS 19. 


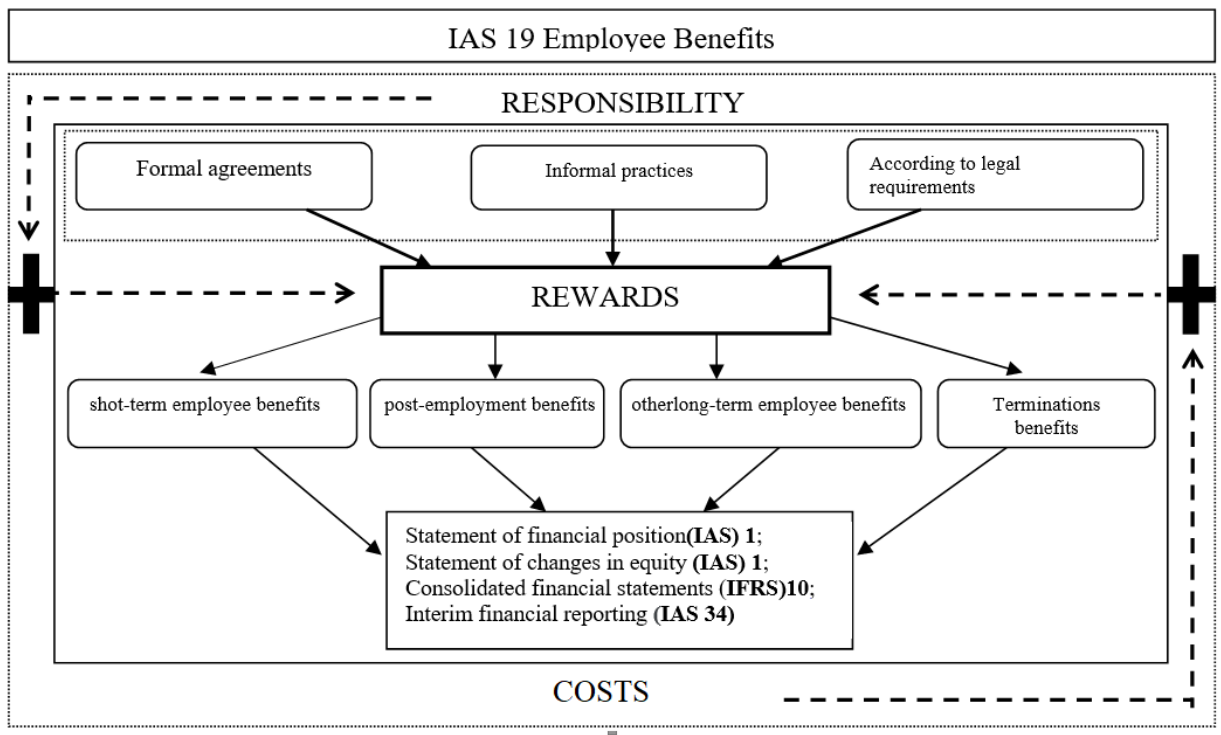

Fig. 3. The structure of the procedure for reflecting information in financial statements, pursuant to the requirements of IAS 19.

Analysis of Figure 3 indicates a complex hierarchy of interactions and complementarities of the procedure for reflecting remuneration expenses in the financial statements. Thus, we note the special role of such criteria for recognizing the fact of remuneration as responsibility and expenses, in our opinion, they can be supplemented based on the practice of applying accounting elements. The proposed format of assumptions on the occurrence of events related to the receipt of remuneration can also be enhanced considering the capabilities of employees in the context of the development of noonomics. The classification of remuneration requires further research on the relevance, completeness and modernity of the assessment of labor results against the background of changes and new forms of interventions (transformations) in the business environment of companies.

The general requirements of IAS 1 allow us to conclude that it is necessary to disclose only those judgments that meet certain conditions, and the most complex and subjective judgments should be able to determine the characteristics of items in the financial statements.

The analysis of the above-described sources of information allows to conclude that during the transformation of the business environment, under the influence of various factors, as well as under the influence of Covid-19, all events become even more uncertain, which means that the likelihood of risks and problems increases. Table 1 presents the proposed basic accounting criteria for the classification of risks in the organization of accounting for labor costs in 2021. 
Table 1. Process approach to the formation of criteria for classifying the risks of organizing accounting for labor costs.

\begin{tabular}{|c|c|c|c|c|c|}
\hline \multirow{2}{*}{$\begin{array}{c}\text { No } \\
\cdot\end{array}$} & \multicolumn{2}{|c|}{ Name } & \multirow{2}{*}{ Content } & \multirow{2}{*}{ Process } & \multirow{2}{*}{ 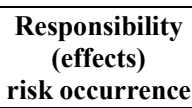 } \\
\hline & Criterion & Risk & & & \\
\hline \multirow{3}{*}{1} & \multirow{3}{*}{$\begin{array}{c}\text { By } \\
\text { designation }\end{array}$} & $\begin{array}{l}\text { Esti } \\
\text { mate } \\
d\end{array}$ & $\begin{array}{l}\text { Risk associated } \\
\text { with order and } \\
\text { timing of } \\
\text { settlements with } \\
\text { employees } \\
\end{array}$ & $\begin{array}{l}\text { A) A new approach to determining the } \\
\text { minimum wage from } 2021 \text {; } \\
\text { B) Indexation of wages; } \\
\text { C) Obligatory accounting of working } \\
\text { hours. }\end{array}$ & $\begin{array}{l}\text { Disciplinary } \\
\text { Administrative } \\
\text { Criminal }\end{array}$ \\
\hline & & Tax & $\begin{array}{l}\text { Risk of correct } \\
\text { withholding of } \\
\text { personal income } \\
\text { tax (hereinafter, } \\
\text { PIT) }\end{array}$ & $\begin{array}{l}\text { A) Personal income tax on wages } \\
\text { through subsidies to small and } \\
\text { medium-sized businesses from the } \\
\text { most affected industries from Covid- } \\
\qquad 19 ; \\
\text { B) New approaches to the formation } \\
\text { of tax deductions; } \\
\text { C) Combining 6-NDFL with 2-NDFL. }\end{array}$ & $\begin{array}{l}\text { Administrative } \\
\text { Criminal }\end{array}$ \\
\hline & & $\begin{array}{l}\text { Acco } \\
\text { untin } \\
\mathrm{g}\end{array}$ & $\begin{array}{l}\text { Regulatory Risk } \\
\text { and Accounting } \\
\text { Methodology } \\
\text { for } \\
\text { Remuneration } \\
\text { Transactions in } \\
\text { Applying IFRS }\end{array}$ & $\begin{array}{l}\text { A) Taking into account the } \\
\text { assumptions in cases of occurrence of } \\
\text { events; } \\
\text { B) Accounting for the recognition of } \\
\text { the onset of one-stage criteria for the } \\
\text { emergence of remuneration. }\end{array}$ & Disciplinary \\
\hline \multirow{3}{*}{2} & \multirow{3}{*}{ In order } & $\begin{array}{l}\text { Com } \\
\text { pens } \\
\text { atory }\end{array}$ & $\begin{array}{l}\text { Risk associated } \\
\text { with } \\
\text { compensation } \\
\text { for the } \\
\text { accounting of } \\
\text { labor } \\
\text { remuneration } \\
\text { transactions } \\
\end{array}$ & $\begin{array}{l}\text { A) Mandatory the sequence of } \\
\text { granting vacations; } \\
\text { B) Calculation of the average daily } \\
\text { salary of an employee and his } \\
\text { compensation for leave; } \\
\text { C) Accounting for non-working days } \\
\text { and their impact on average wages }\end{array}$ & $\begin{array}{c}\text { Disciplinary } \\
\text { Administrative }\end{array}$ \\
\hline & & $\begin{array}{l}\text { Insur } \\
\text { ance }\end{array}$ & $\begin{array}{l}\text { Risk of correct } \\
\text { calculation of } \\
\text { insurance } \\
\text { premiums }\end{array}$ & $\begin{array}{l}\text { A) Accounting the size of the limit } \\
\text { base from 2021; } \\
\text { B) Reduced tariffs from April 1, } 2020 \\
\text { for SMEs and from January 1,2021 } \\
\text { (Covid-19); } \\
\text { B) Features of the calculation and } \\
\text { payment of contributions for separate } \\
\text { subdivisions }\end{array}$ & $\begin{array}{c}\text { Disciplinary } \\
\text { Administrative }\end{array}$ \\
\hline & & $\begin{array}{l}\text { Subs } \\
\text { idiar } \\
y\end{array}$ & $\begin{array}{c}\text { Risk of } \\
\text { Appropriate } \\
\text { Application of } \\
\text { Subsidies to } \\
\text { Support SMEs } \\
\end{array}$ & $\begin{array}{c}\text { A) Taxation of personal income tax } \\
\text { on wages through subsidies to small } \\
\text { and medium-sized businesses from } \\
\text { the industries most affected by Covid- } \\
19 ;\end{array}$ & Disciplinary \\
\hline \multirow{3}{*}{3} & \multirow{3}{*}{$\begin{array}{l}\text { By } \\
\text { reporting } \\
\text { forms }\end{array}$} & $\begin{array}{c}\text { 6- } \\
\text { NDF } \\
\text { L }\end{array}$ & \multirow{3}{*}{$\begin{array}{l}\text { Risks of filling } \\
\text { in the relevant } \\
\text { reports (reliable, } \\
\text { complete and } \\
\text { timely data) }\end{array}$} & $\begin{array}{l}\text { A) Features of reflection of carry-over } \\
\text { amounts of income, amounts of } \\
\text { hospital benefits, bonuses, vacation } \\
\text { pay, etc. in 6-NDFL. } \\
\text { B) Penalties for errors in personal } \\
\text { income tax reports. }\end{array}$ & $\begin{array}{c}\text { Disciplinary } \\
\text { Administrative }\end{array}$ \\
\hline & & $\begin{array}{c}4- \\
\text { FSS }\end{array}$ & & A) New form 4-FSS. & $\begin{array}{c}\text { Disciplinary } \\
\text { Administrative }\end{array}$ \\
\hline & & $\begin{array}{l}\text { SZV } \\
\quad- \\
\text { STA } \\
\text { ZH, } \\
\text { SZV } \\
\text {-TD }\end{array}$ & & $\begin{array}{c}\text { A) Calculation of insurance } \\
\text { premiums, SZV-STAZH, SZV-M, } \\
\text { SZV-TD } \\
\text { B) Recommendations for the } \\
\text { formation of indicators of reporting } \\
\text { forms }\end{array}$ & $\begin{array}{c}\text { Disciplinary } \\
\text { Administrative }\end{array}$ \\
\hline
\end{tabular}

Thus, Table 1 indicates a variety of regulatory changes, partial initiatives to consider transformations of wages, as well as requirements for tax deduction for personal income tax, 
receiving subsidies from small businesses, reflecting recalculations of wages in the reporting, calculating insurance premiums. Risks as a probabilistically oriented category, in our opinion, should form a balanced approach to assessing the situation and environment of the company.

\section{Conclusions}

Summarizing the results obtained and systematizing scientific views on the problems of accounting for costs and motivation of remuneration in the context of the digitalization of the economy, we can note the difficulties caused by the continuously transforming events and processes of endogenous and exogenous factors of the environment of companies' activities. The scientific results allowed us to make a conclusion on the revision of the place and value of human capital in the context of the digitalization of the economy and the intensification of this process in the context of the spread of Covid-19, the search for efficient solutions in the field of methodology of accounting processes, as well as the increasing importance of the transition of financial reporting to international reporting standards. The authors noted the relationship between compliance with the requirements for wage accounting, its sequential processes and staff motivation.

Analysis of information sources allows us to conclude that during the transformation of the business environment, under the influence of various factors, as well as under the influence of Covid-19, all events become even more uncertain, which means that the likelihood of risks and problems increases. Thus, the result of the study was the identification of the main risks in the organization of remuneration, settlements with personnel in modern conditions and considering legislative innovations. Thus, it was noted that during the Covid19 period, the governments of many countries make decisions in terms of developing solutions to form mechanisms to counter the Covid-19 virus, restarting economies and providing conditions that enhance the survival of the population (compensation payments and support). The authors systematized the main risks pursuant to a number of basic accounting criteria: the purpose of transactions in accounting, the procedure for settlements and reflection, and reporting forms. The features of the process approach to the formation of accounting procedures, considering the conditions of digital transformations of operations related to the operations of accrual, withholding and payment of wages, are revealed, where, in contrast to the existing approaches, aspects of the influence of endo- and exogenous factors in the dynamics of the development of digital transformations are systematized. Structural analysis of the main provisions of the international standard IAS 19, which made it possible to critically assess the structure and procedure for reflecting information in the relevant financial statements.

\section{References}

1. E. Amir, J. of Accounting, Auditing \& Finance 11(3), 427 (1996)

2. V. Anikin, J. of institutional studies 10, 90 (2018) http://doi.org/10.17835/20766297.2018.10.2.090-117

3. O. Ageeva, Vestnik Universiteta 3, 123 (2020). http://doi.org/10.26425/1816-42772020-3-123-126

4. I. Britchenko, Proceedings of the 2nd International Conference on Social, Economic and Academic Leadership (ICSEAL 2018) 217, 169 (2018) 
5. R. Blizkyi, V. Malinenko, Y. Lebedinskaya, Recursion of the Temporal Paradigm of the Digital Economy Accounting Socio-economic Systems: Paradigms for the Future, 314, 54 (2021). doi.org/10.1007/978-3-030-56433-9_54

6. R. Blizkyi, V. Malinenko, Y. Lebedinskaya, Socio-economic systems: paradigms for the future 137, 314 (2021) http://doi.org/10.1007/978-3-030-56433-9_137

7. K.S. Gavrish, Bulletin of Adygea State University 3(245), 73 (2019)

8. K.S. Gavrish, Bulletin of Adygea State University 4(250), 168 (2019)

9. D. Miele, A. Scholer, Educational Psychologist 53(1), 1 (2018) http://doi.org/10.1080/00461520.2017. 1371601

10. E. Mendoza, V. Quadrini, J. of Political Economy 117(3), 371 (2009)

11. J. Naughton, Review of Accounting Studies 24, 456 (2019)

12. PwC Academy: ACCA training DipIFR (2020).https://training.pwc.ru

13. I. Rakhmeeva, European Research Studies Journal 21(2), 624 (2018) http://doi.org/10.35808/ersj/1289

14. J. Romich, Social Service Review 80, 27 (2006).

15. J. Smith, Z. Rezaee, International Advances in Economic Research 1(4), 426 (1995)

16. T. Zafar, Effect of compensation on employee motivation (Study on BPRS in Sukabumi Regency/City), (2021) https://doi.org/10.31219/osf.io/a5dyb

17. IFRS: IAS 19 Employee Benefits (2021). https://www.ifrs.org

18. T. V. Tselyutina, O. A. Timokhina, T. A. Vlasova, Y. V. Maslova, Int. J. of Supply Chain Management 8(5), 1030 (2019)

19. T. V. Tselyutina, T. A. Vlasova, O. A. Timokhina, Y. V. Maslova, Int. J. of Supply Chain Management 8(5), 1039 (2019) 